\title{
Narrative as a Pedagogical Method and Quality of Pre Service Moral Education Teachers
}

\author{
Nur Surayyah Madhubala Abdullah ${ }^{a}$, Maizura Yasin ${ }^{\mathrm{a}}$, Norzihani Shaharuddin \\ ${ }^{\text {a } F a c u l t y ~ o f ~ E d u c a t i o n a l ~ S t u d i e s, ~ U n i v e r s i t i ~ P u t r a ~ M a l a y s i a, ~} 43400$ UPM Serdang, Selangor, Malaysia. \\ ${ }^{\mathrm{b}}$ Department of Social Foundation \& Educational Leadership, Kuliyyah of Education, International Islamic University \\ Malaysia \\ Corresponding e-mail: nsurayyah@upm.edu.my
}

\begin{abstract}
This paper explores how narrative can be used as a pedagogical method in improving quality of pre-service moral education teachers. It examines the use of stories to engage students' experiences with moral behavior of people and the ethical basis for their behavior to achieve the learning outcomes. Further, it considers ways in which these experiences are used to influence their understanding of being a moral person with regards to being a Moral Education teacher. It suggests how sharing and discussing experiences help students develop deep learning about the teaching of Moral Education-what it is and how it should be taught. The main author's experience as a teacher educator who used narrative in teaching a humanities course for pre-service teachers is explored. Data in the form of themes that emerged from the author's reflections are presented to describe personal experiences of herself as a teacher educator in a pre-service teacher education programme on the use of narrative, its contributions and the difficulties faced in the context of developing quality pre-service teachers. Discussion considers the benefits and challenges of using narrative as a pedagogical method in pre service education of moral education teachers. Findings show that narrative can play a useful role in helping pre-service teachers understand themselves as future Moral Education teachers, and what it means to teach Moral Education and what is important in teaching and learning of Moral Education. In addition, it can be used to assist preservice teachers to have a proper understanding of the implication of teaching Moral Education in a plural society.
\end{abstract}

Keywords: Moral Education; narrative; pedagogical method; pre service teachers; teacher education; teaching and learning in higher education; teaching humanities

\section{INTRODUCTION}

Teaching is a complex and multidimensional process that requires deep knowledge and understanding in a wide range of areas and the ability to synthesize, integrate, and apply this knowledge in different situations, under varying conditions, and with a wide diversity of groups and individuals. In quality teaching, this knowledge is applied in ways that provide equitable access and opportunities that build upon and extend what learners already know in facilitating the ability to acquire, construct, and create new knowledge. (Hollins, 2011) 
This being the case, the main concern of any teacher education programme should be the quality of teachers produced where quality relies on the teacher preparation programme (Cochran-Smith and Lytle, 1999; Darling-Hammond, 1994; Bullough et.al., 2002). However, there is concern whether teacher education programmes can actually improve the quality of teachers when how this should be achieved lacks clarity (Walsh, 2006). Nevertheless, what is established is that teacher quality does make a difference to student achievement (Hattie, 2009) where quality is understood in terms of student achievement. Therefore, if teacher education programmes want to produce quality pre-service teachers, they should focus beyond subject matter knowledge to developing the ability of pre-service teachers to use that knowledge effectively in teaching (Hattie, 2012). Effective use of knowledge among pre-service teachers in their teaching requires a deep understanding about the content including their beliefs teaching and learning of the subjects they teach. Hattie describes this as "visible learning" (2009).

Within the concern expressed in literature about producing quality teachers through teacher education programmes and methods of doing so, this paper considers narrative as a pedagogical method in the teaching of pre service moral education teachers. It discusses the role, benefits and challenges of using narrative based on the case of the corresponding author's experience of using student narratives in teaching and learning of a course on Moral Philosophy in a teacher education programme in Moral Education in a university in Malaysia.

The paper begins with the background to Moral Education in Malaysia and a consideration quality in pre-service moral education teachers; narrative as pedagogical method in teacher education; and the use of narratives in teaching and learning of pre service teacher courses. The theoretical framework of this paper is also framed in this part. A brief review of literature on the use of narratives in pre service teacher education follows. Next, the paper outlines the course and how narrative was used in teaching and learning. This is followed by a list of themes that emerged from the reflection on its use. The paper concludes with a considered observation on the use of narrative in pre-service teacher education, its contribution to the quality of pre service teachers in Moral Education and some thoughts for teacher educators on using narrative.

\section{BACKGROUND}

\subsection{Moral Education in Malaysia}

Briefly, Moral Education is a core subject in the Malaysian School Curriculum and part of its formal values education programme. Introduced in 1983, the subject was fully implemented at all levels in 1989. In order to emphasise its importance in the school curriculum and to ensure that the subject was taken seriously by all parties specifically students, parents, teachers and school administration, the subject was made examinable subject. Students have to sit for the Moral Knowledge paper at the Malaysian School Certificate level. However, only non-Malay students are required to take the subject. Muslim students are required to take Islamic Education although nonMuslim students are allowed to choose to study the subject. The converse is not true for Moral Education and Muslim students. "The perspective is that Islamic education already has a value component through the idea that religion is morality and hence Muslim students already learn about morality and moral values and behaviour from the religious classes. In addition, moral values and behavior are in taught across the curriculum through other subjects and, is also delivered through the informal curriculum and the school ethos" (Nur Surayyah Madhubala Abdullah, 2015). Therefore Muslim students already have adequate instruction in morality and do not require a further class in the subject. Another reason is the concern that morality has to be seen from an Islamic perspective and should be taught by Muslims which in the case of Moral Education would not be the case.

Recent changes to the curriculum based on the Malaysia National Educational Blueprint (2013-2025) have not changed the status quo of the subject in the school curriculum. However, the nature of the subject, its contents, learning outcomes and assessment have changed with the shift towards a philosophical approach to Moral Education Curriculum with the introduction in 2017 of the Standard Curriculum for Moral Education (2017). Consequently, teacher preparation has shifted from preparing teacher to just transmitting values to developing teachers who recognize the significance of moral, social and civic values in the lives of students as individuals in the Malaysian and global society context towards the betterment of humanity.

Despite the long history of the subject in the school curriculum, its prominence as a core subject 
and the continued emphasis on the subject in the Blueprint, there exists a problem of teacher quality among Moral Education teachers in Malaysia. However, this problem is more an issue of lack of trained teachers. Nevertheless, the problem of teacher quality is documented as being urgent and requiring research. This is because the quality of pre service teachers being produced by Faculty of Educations where teacher education Programmes for Moral Education teachers are offered is a cause for concern as it is under researched.

However, anecdotal evidence from formal observations and reports on pre service moral education teachers attitude and practices during their teaching practicum over a period of nine (9) years by the corresponding author in her role as supervisor on teaching practicums as well as feedback obtained through discussions with other supervisors strongly suggest that pre-service Moral Education teachers are unable to relate their knowledge about moral education with their understanding of their role as moral education teachers, objective and aims of moral education and Moral Education as a subject, what they are to teach, how they should teach and for what purpose. In addition, there is sense that they do not fully appreciate the nature and value of Moral Education as a field and as a subject in the school curriculum. There is a lack of critical understanding of the nature of the content they are teaching, and how that relates to their teaching and the learning of their students. One of the reasons, this teacher educator observed, is the pedagogical method employed in teaching and learning of courses in their core courses.

Literature reviewed strongly points to the importance of pre service teacher education because 'the way teachers teach is of critical concern in any reform designed to improve quality' (UNESCO 2005:152). In particular 'the methodologies used (including how to combine theory, practice and personal experience in a constructive way' is important (University of Sussex 2003:cited in Watson , 2015). Therefore, this paper explores the use of narratives in developing deep learners among pre service Moral Education teachers towards improving their quality.

\subsection{Quality of pre service Moral Education teacher}

Quality in teachers is about their phronesis " ...a comprehensive moral capacity which combines practical knowledge of the good with sound judgement about what, in a particular situation, would constitute an appropriate expression of this (Carr, 1995, p.71)." (Nur Surayyah Madhubala Abdullah, 2015, p.13-14). In this sense, the quality of pre service Moral Education teachers refers to their ability to educate for morality. Educating for morality is about educating about the moral domain and what that entails (Barrow, 2007). Based on Kiss \& Euben (2010), quality of pre service moral education teachers should be situated "in both the character of the teacher and the performative dimensions of his or her teaching" and not only in the content they teach. This suggests that in developing quality pre service Moral Education teachers, teacher educators should give adequate focus on how they are teaching and what approach and method they are using to make an impact on moral education pre service teachers' teaching behaviour- how they teach about the moral domain. This involves developing their phronesis as prospective Moral Education teachers about morality, moral education and the teaching and learning of Moral Education. The problem is the quality of pre service Moral Education teachers produced by Faculty of Educations are questionable due to scarcity of research. However, it is known that the approach to teaching of pre service teacher courses does contribute to their quality (Bullough et.al. 2002; Hammond, 2005, 2006). Therefore, any experience of teaching pre service moral education teachers, approach or methods used and the challenges faced can contribute to a better understanding of developing quality teacher education programmes specifically those in Moral Education.

\subsection{Narrative as pedagogical method in pre service teacher education}

Narrative and education are intrinsically linked. According to Oakeshott "education is a transaction between teachers and learners" (p. 23). "It is in teaching and learning' that education takes place" (p. 68). Education includes the experience of a student that involves experience cultivation, awakening, and transformation (Connelly \& Clandinin, (1995, p. 82). To be educated involves the narrative of what has occurred to the student during the teaching and 
learning process. Narrative here refers to the "process of meaning making" that occurs in teaching and learning. Its importance in education is acknowledged as it helps to bring about deep learning. In pre-service teacher education deep learning is about improving critical thinking and metacognitive skills towards improving and enhancing their learning about teaching and being a teacher.

\subsection{Use of narrative in teaching and learning of pre service Moral Education teachers}

In the context of teacher education, education is to develop an individual who can act for the good of society. In this sense, facilitating deep learning- the ability to transfer their knowledge to the classroom is important to develop teachers who are capable of practical wisdom -connecting theory to practice in the real context of the classroom to achieve the desired outcomes. Therefore, using narrative in teaching pre service teachers refers to a teaching strategy that utilizes storytelling or narratives of students' own experiences of engagement as basis of teaching and learning to achieve critical understanding of content. The focus is on authentic engagement with the content of a course.

\subsection{Theoretical framework}

This problem of using narrative as a pedagogical method in improving the quality of pre-service teachers in teacher education programmes can be contextualised within the ideas of teacher preparation and teacher quality; teaching in higher education and issues in teacher preparation and philosophical and developmental perspectives about educating for morality. This articulation of pre-service teacher quality and teacher education programmes suggests that teacher educators in their teaching and learning should focus on adopting pedagogical methods that enable and facilitate preparation of pre-service teachers who have a deep appreciation of what they teach rather than just knowledge of what they teach. For social science teachers, it is also important to recognise the implication of what they teach and what they are asked (curriculum) to teach, on their students learning including on their beliefs, values and practices (Hollins, 2011). For teaching subjects in Humanities such as Moral Education, the need is greater as teaching and learning deals directly with issues of values and morality that are underpinned by beliefs of a person. Without adequate acknowledgement of what is involved in teaching and learning of Moral Education in moral terms such as social justice, rights and welfare, and acceptance of this reality such as the kind of morality and moral person they contribute to through their teaching and learning, pre service teachers may ignore the influence their teaching has on the kind of morally educated person that is produced.

Therefore, in researching the education of preservice moral education teachers specifically in finding ways to improve the quality of pre service teacher's, aspects of their preparation should be the one of focus areas that should be given consideration by researchers. In particular, teacher educators in the field of moral education, if they are concerned about improving the quality of pre-service teachers and their influence on student achievement in Moral Education, should explore pedagogical methods used in teaching and learning courses particularly the core courses related to moral education such as moral philosophy, moral issues and moral development and teaching of moral education.

A recent study (Kalaiselvi Etikan et al., 2017) into the notion of quality in secondary school Moral Education teachers in Malaysia raises concerns about the need to focus on better conceptualisation of preparation of pre-service Moral Education teachers in teacher education programmes and the idea of standard and quality in teacher preparation in this subject. The findings suggest that the notion of quality in Moral Education teachers requires more articulation so that teacher standards can be appropriate not only to the subject matter but to teacher experience. This involves providing a proper framework of teacher quality including at pre-service level in teacher education programmes. This further strengthens the need to consider teacher educators' pedagogies in pre service teacher education programmes.

\section{USE OF NARRATIVE IN TEACHING MORAL PHILOSOPHY}

\subsection{The course}

In brief, the Moral Philosophy course is one of five courses in the Moral Education Programme offered as a minor to Bachelor of Education (Guidance and Counselling) Programme (B.Ed. (Guidance \& 
Counselling)) in the university where the corresponding author is attached. She has been teaching this course since 2015. The course is a three (3) credit course which was split into one 2 hour class and a 1 hour class. Based on the course outline, the major aim of this course is to educate pre service teachers about the philosophical background of moral stands and its implications for teaching and learning of moral education (Appendix A).

\subsection{The students}

The students in this course were in their $4^{\text {th }}$ semester (2nd year) of their programme. The corresponding author has taught them another core course the previous semester. As such the students and the author had built a rapport and were quite comfortable with each other in terms of their teaching and learning style and teaching environment. There was a "just community" in the class and discussion and reflection had been in place as part of active learning approach adopted by the author and formed her basis of teaching and learning in the class.

\subsection{Teaching and learning approach}

Active learning was used as the main guiding approach and influenced the teaching and learning strategy and hence the methods chosen.

\subsection{The class}

The structure of the class started with lecture on a particular theory. Active learning techniques such as class/group discussion were used stimulated by inclass assignments questions (Appendix B). The lecture was two hours. Prior to the start of the lectures, students were provided with a List of Narrative Topics (Appendix C). These topics were to be used to share stories and observations based on their own experiences or those of others that they were privy to or had knowledge of. The sharing of 'student's narrative' were done during the one hour period. During this 'sharing session' students sat in a circle and three students were assigned to each topic to provide their narrative-story based on the topic assigned to them in the list of narrative topics provided. During the "sharing sessions" student listened to their friends stories. After each story was told, other students were invited to share their own narratives of what they had heard and share any stories they had. This was done for all the students sharing on a particular topic. The author also shared her stories.

Next, students were invited to raise questions, comment and make observations about the theory upon which the narratives were based. This step was used by the author to draw attention to the main elements of the theory -to improve their understanding. It was also used by the author to generate critical thought on the nature of morality, moral education and their future role as moral education teachers and current role as students learning to be Moral Education teachers. This was done by the author who posed amongst others questions that stimulated such thought including using questions that challenged their thoughts(such by asking whether this was the case in their own situations) as well questions that probed into their emotions about a particular morality (such as by exploring their feelings if this was to happen to them or if this idea of morality should be the case in a plural society where students from different backgrounds could hold different ideas about morality and perceived good or bad behaviour differently).

In addition to the narrative topic list, students had been given a narrative response form. The author had explained prior to the start of teaching of the course, during introduction to the course, that students during the "sharing of stories" would be asked to reflect on the stories they heard and other narratives that emerged during the class including observations, comments and arguments and write their comments in a Narrative Response Form (Appendix D).

In order to facilitate continued discussion that may arise from the 'sharing sessions', students were asked to share their thoughts on a Whats App group that had been created for the course as well as an Edmodo group (Appendix E).

\section{REFLECTIONS}

Based on the author's reflections on using narrative in teaching a humanities course in a pre-service Moral Education Programme, several themes were identified. In terms of its use, the themes are 
enlightening, educative, and empowering and motivating. In terms of its contributions, the themes that emerged are gives voice, democratic classroom and ownership of learning. Finally on the challenges, the themes are time consuming, sensitive content, and handling conflicting ideas. The findings show that narrative as a pedagogical method can play a useful role in helping pre-service teachers understand themselves as future Moral Education teachers, and what it means to teach Moral Education and what is important in teaching and learning of Moral Education. In addition, it can be used to assist preservice teachers to have a proper understanding of the implication of teaching Moral Education in a plural society. This is because though the sharing of individual narratives the student in learning to be a Moral Education teacher is experiences the morality of teaching and learning of Moral Education through the engagement with moral theories and its implications for the behaviour of individuals or groups opens the students to questioning, challenging and rethinking their views about morality, moral education, their role as Moral Education teachers and the teaching and learning of Moral Education. These outcomes are not only of a cognitive nature but affective as well.

\section{CONCLUSIONS}

Based on a considered observation on the use of narrative in pre-service teacher education and its contribution to the quality of pre-service teachers in moral education, it is suggested that narrative as a pedagogical method can assist in a certain sense in developing pre-service teachers who are more aware of who they will be as Moral Education teachers. In the process, the use of stories make the learning personal and something that allows them to associate their learning in a genuine manner with themselves as professional educator albeit Moral Education teachers. However, the use of narratives requires an atmosphere of trust, sincerity and openness for it to play an effective role in developing quality teachers. In addition, the instructor should be prepared to listen without judgement. Teacher educators who would like to use narrative in the classroom should provide non-disclosure forms to protect the privacy of the students. The ethics of using this approach in the class such as vulnerability of the students to what is shared and is being shared by others should be particularly attended to before the class begins. Further proper planning and running of the activity is paramount. However, what is ultimately important is time- time to discuss! Student feedback after the course about the method showed that they valued the chance to bring their narratives into the course content. What was lacking was the time to discuss and share more stories. Use of social and educational sites is one way. However, it is important that the course instructor is involved in that discussion as well. The students value adult and expert feedback that is constructive and thought provoking.

\section{REFERENCES}

Barrow, R. (2007). An Introduction to Moral Philosophy and Moral Education. London: Routledge.

Bullough, R.V.,Jr., Young, J., Erickson, L., Birrell, J.R., Clark, D.C. \& Egan, M.W. (2002). Rethinking Field

Experiences: Partnership Teaching versus Singleplacement Teaching. Journal of Teacher Education, 53,1 ,

$68-80$.

Connelly, F.M., \& Clandinin, D.J. (1995). Narrative and Education. Teachers and Teaching, 1,1, 73-85. DOI: 10.1080/1354060950010106

Darling-Hammond, L. (Ed.). (1994). Professional Development Schools: Schools for Developing a Profession. New York: Teachers College Press.

Hattie, J. A. C. (2012). Visible learning for teachers. London: Routledge.

Hollins, E. R. (2011). Teacher preparation for quality teaching. Journal of Teacher Education, 62, 4,395407.

UNESCO. (2005). EFA Global monitoring report: Education for all-The quality imperative.

Kalaiselvi Etikan, Nur Surayyah Madhubala Abdullah, \& Nurzatulshima Kamarudin, . 2017.

Kiss, E. \& Euben, P.J. (2010). Defining moral education. Inside Higher Education.

https://www.insidehighered.com/views/2010/02/01/definingmoral-education

Nur Surayyah Madhubala Abdullah. (2015). Moral Education in Malaysia and the notion of quality in Moral Education teachers. Plenary Speech delivered at the International Conference on Education in Muslim Society (ICEMS), 12 November 2015, State Islamic University(UIN), Syarif Hidayatullah Jakarta, Jakarta, Indonesia. 
Watson, C. 2015. Quality in education teacher education and professional development.

http://www.globaltfokus.dk/images/Pulje/Arkiv/Uddannelsesnetvae rket/Quality_in_Education_-

_A_literature_review_-_21.01.2015.pdf 